\title{
MANAGEMENT GUIDELINES OF RESIDENT ANESTHESIA AND INTENSIVE THERAPY BASED ON NEEDS INTHE INTENSIVE CARE UNIT AT HOSPITAL HOSPITAL DR.KARIADI SEMARANG
}

\author{
Danu Soesilowati* \\ Education Management, Universitas Negeri Semarang, \\ Dr. Kariadi, Central General Hospital \\ danusoesanto@gmail.com \\ Tri Joko Raharjo \\ Education Management, Universitas Negeri Semarang, \\ trijokoraharjo@mail.unnes.ac.id \\ Arief Yulianto \\ Education Management, Universitas Negeri Semarang, \\ ariefyulianto@mail.unnes.ac.id. \\ Heri Yanto \\ Education Management, Universitas Negeri Semarang, \\ heri.yanto@mail.unnes.ac.id
}

\section{Publication History \\ Manuscript Reference No: IJIRAE/ RS/ Vol.07/ Issue08/ AUAE10080}

Received: 30, July 2020

Accepted: 10, August 2020

Published Online: 14, August 2020

DOI: https:// doi.org/ 10.26562/ijirae.2020.v0708.001

Citation: Danu,Tri,Arief,Heri(2020). Management Guidelines of Resident Anesthesia and Intensive Therapy Based on Needs in the Intensive care at Hospital Dr.Kariadi Semarang. IJIRAE:: International Journal of Innovative Research in Advanced Engineering, Volume VII, 310-317. https:// doi.org/ 10.26562/ijirae.2020.v0708.001

Peer-review: Double-blind Peer-reviewed

Editor-Chief: Dr.A.Arul Lawrence Selvakumar, Chief Editor, IJIRAE, AM Publications, India

Copyright: (2020 This is an open access article distributed under the terms of the Creative Commons Attribution License, Which Permits unrestricted use, distribution, and reproduction in any medium, provided the original author and source are credited

\begin{abstract}
Intensive Care Unit (ICU) is one of the rooms in the hospital that has independence because of its role in serving emergency diseases. The presence of a doctor on duty in the ICU will be adjusted to the level of the ICU and the number of emergency patients in the ICU. Therefore we need a doctor who is specialized in dealing with this. The guidance of ICU resident mastery of Anesthesia and Intensive Care is needed to improve competence. Resident must be able to learn to reach the target through good and right coaching. The purpose of this study is to describe the management of the guidance of resident Anesthesia and Intensive Therapy based on needs in the ICU. Qualitative research approach with Case Study type. Anesthesia resident research subjects in Dr. RSUP Kariadi Semarang. The results showed the management function has not been implemented to the fullest. Need-based guidance management still needs to be developed, Guidance planning is only carried out in the same direction, so that it will reduce the significance of the guidance. The organization of residents related to needs-based counseling only exists from and between stations, the direction or mobilization of residents in need-based mentoring is good and there are still shortcomings related to the consistency of coaching. Model control is carried out properly through supervision, monitoring, and evaluation. Recommendations are given to related parties to design, formulate and manage resident coaching appropriately.
\end{abstract}

Keywords: Management, anesthesia, guidelines, resident, Intensive

\section{INTRODUCTION}

The Intensive Care Unit (ICU) is part of a stand-alone hospital and is a treatment room with a high risk of patient death. This is indicated by the findings of several studies, including the results of a Personal study in 2012, showing that in a period of 2 years, 103 patients were recorded to have undergone carniotomy which were later treated at the ICU, there were 51 patients died and 52 patients were alive. 
In the ICU mortality rates in RSUP Dr. Kariadi during the period of 4 months, January to April 2012 around 24.23\% (79 people), where $75.9 \%$ of them died after being treated for more than 48 hours and $8.8 \%$ died due to respiratory failure [1]. At the ICU hospital doctor Kariadi showed the number of ICU patient deaths was 81 out of a total of 493 patients. The high number of deaths in the ICU includes a limited amount of space, while the number of patients who need an ICU is very high. The hospital will set criteria that are the priority of patients entering the ICU [2]. In the another research, also showed that ICU patients could not be separated from the use of ventilators. Therefore it is necessary to examine how to explore the implementation, prevention and control of Ventilator Associated Pneumonia (VAP) [3]. Fast and precise medical services are needed to save patients. Rapid decision making supported by data is the result of continuous observation and monitoring which is the main task of specialist doctors and paramedics who work in the ICU. The level of busyness and high standard of care requires ICU management and high technology equipment.

The Intensive Anesthesia and Therapeutic Specialist Education Program was opened to meet the needs of Intensive Anesthesia and Therapeutic Doctors at the ICU. Resident as a student will follow the learning process to become part of specialists who help fully in hospital assignments. Resident must learn many things related to ICU and ICU services. The complex mechanism of illness and emergency requires careful coordination and continuous supervision. The presence of a doctor on duty at the ICU will be adjusted to the ICU level and the number of emergency patients in the ICU. Therefore we need a doctor who is specialized in dealing with this.

A resident in addition to his role in the specialist medical education program as a student, he must also be able to provide guidance to co-assistants (medical education students who are conducting clinical education rotations in this supervisory assignment are one of the requirements in the Specialist Medical Education Program. Resident has the potential great in interacting with co-assistant, therefore it must have adequate provision in interacting and doing coaching.

Resident in taking specialist doctor program, will follow simulation-based training [4]. Simulation-based training is carried out in 2 (two) groups, namely experiment and control. The experimental group will carry out procedural training activities without supervision. Both groups will have the convenience of doing procedural up to $47 \%$ for the treated group and $26 \%$ of the control group in the Central Veneous Catheter (CVC) training with p. 0.051. Procedural convenience of up to $47 \%$ owned by groups treated for ICU experience training will be influential teachers for future professions [5].

Professionalism is quality and behavior that characterize a profession or a professional. Professionalism is included in the area of Indonesian Doctors Competency Standards [6] which have taken note of the direction of globalization in the field of medical education. Professionalism is a basic contract that must be held in the relationship between the medical world and the general public, this is because doctors have been given special authority by the general public that should not be misused [7]. One of the supports of professionalism is the mastery of professional competencies that must be possessed. A doctor's professional competence is built from scientific knowledge, clinical skills and moral development [8]. Therefore, to build the competence of Anesthesiologists, specialists need to be done intensively and based on established standards[9].

Anesthesia Resident provides direct services to patients, works under the control of hospitals and medical schools. Anesthesia Resident and Intensive Therapy are aspiring practitioners, clinicians, and educators in the field of Anesthesia. Therefore residents must be encouraged and supported in order to be able to get a comprehensive understanding of the principles of professionalism, including the ability to maintain the boundaries of relationships with patients, colleagues, and other related professions.

Observations made on a number of residents, medical personnel, nurses, administrative staff and other ICU managers, identified data as follows: 1) $48 \%$ of doctor and resident services at ICU $48 \%$ are good, $35 \%$ are quite good, and $17 \%$ state they are lacking; lack of perception among them caused by doctors and residents less competent, less communicative, and lack of attention; (2) the resident services at the ICU are $65 \%$ good and the rest are sufficiently noted because of the overload of resident duties, and the resident requirements on duty at the ICU; (3) $17 \%$ of respondents gave the perception that it was very necessary for residents to understand clear duties and authority at the ICU, the rest stated that it was necessary; (4) based on the resident's authority, then $57 \%$ stated that the resident had limited authority, according to the level of competence, $35 \%$ stated that the authority was unlimited, just like doctors in the ICU; (5) 39\% of respondents strongly agree that the resident will be guided by a specialist who has the authority, the rest agrees and does not know / do not have an opinion; (6) related to resident guidance guidance procedures $9 \%$ strongly agree with standardization procedures, $61 \%$ agree, $13 \%$ disagree, the rest do not agree; (7) 52\% of respondents stated that monitoring and evaluation of guidance did not support resident professional behavior, the rest stated it was necessary. 
Guidance and assistance activities are carried out by doctor supervisors and needs-based assistants who describe professional and controlled practice situations, a measure of the success of the process can be seen in the results of performance-based assessments conducted during professional practice [10]. The development of medical science today is changing the way of doing a final assessment with a multidimensional and broad assessment that can represent the performance of doctors [11]. This has become strong to influence the performance factors in achieving the final results of education. Guidance that is needed and needs-based will help realize the professional competence of specialist doctors.

Monitoring is needed to ensure that residents are working in accordance with the professional standards of Anesthesia and Intensive Therapy doctors. Monitoring or evaluation will ensure that residents' needs are fully taught and instilled. There are quality controls that produce feedback to make improvements in the process of resident transformation, it is hoped that the education system is able to maintain its existence and improve its performance [12]. This is the importance of the management of doctor services. The doctor must be able to have 1) clinical expertise, 2) communication, 3) collaboration, 4) management, 5) personal development, 6) education, 7) professional attributes, and 8) health and self-care [13]. The need for performance appraisal procedures that can measure the performance of doctors while practicing, has made the topic of performance appraisal the focus of various studies on physician assessment in the field of medical education [13][14], and this need should be a priority in the administration of specialist medical education programs.

Standardized guidance / accompaniment management and performance appraisal; according to the needs of residents Anesthesia and Intensive Therapy has not been maximally implemented. There are many types of resident management in the ICU room. Variations can cause gaps in resident performance [15]. Therefore, a guiding model or strategy is needed that can be used in various specialist medical education facilities available [16] The formulation of a guidance model to improve the competency of prospective specialists in Anesthesia and Intensive Therapy needs to be done by paying attention to the characteristics of the resident.

\section{LITERATURE REVIEW}

Management is a unique process that consists of planning, organizing, mobilizing and controlling actions that are carried out to achieve the goals set [17]. Management involves the activities of coordination and supervision of the work of others, so that the work can be completed efficiently and effectively [18]. Management is also the art and science of achieving goals done through the efforts of others [19].

Management is a process that consists of planning, organizing, directing, and controlling / controlling through the use of organizational resources effectively and efficiently to achieve certain goals. Management has a uniqueness more than just art, management can relate to the most appropriate strategy for managing an organization according to the goals set.

Specialist education in Indonesia trains a general practitioner to become a specialist doctor using established standards [6][9]. The resident is a student of the Specialist Education Program whose role is to treat patients, educate medical teams and junior doctors. Resident will interact with medical students in clinical education. The North America Accreditation Board (American Council for Graduate Medical Education or ACGME) and The Liaison Committee on Medical Education (LCME) formally determine the need for Teaching Skills training in residency programs. A resident will conduct a mentoring process with sufficient competence and experience. This learning experience will be an adequate source of learning for them to complete the education process. Increased resident ability through education and training will bring increased knowledge and procedural readiness independently [4]. A variety of resident learning methods as mentioned above to enhance the resident learning experience. Feedback is done with the aim to improve the quality of learning (process and results). Feedback is very much related to program control which is very related to self control. The process involving mental activity in humans as a result of active interaction with the environment to obtain a change in knowledge, understanding, behavior, and skills requires reinforcement through feedback. The process involving mental activity is a supporting description of cognitive theory, helping students construct knowledge in improving performance and motivation to learn.

Factors determining the educational attainment of feedback from about 180 thousand studies with participants between 20 to 30 million students, found the average feedback was 0.72 . The magnitude of the effect of feedback is almost double the average effect of all learning activities in schools which is 0.40 . From this research, concluded that feedback was among the factors that most influenced learning achievement. Feedback helps students set specific learning goals in all aspects of clinical pregnancy, the accuracy of a student's self-value on his clinical performance [20]. 
Development needs analysis is used to determine the gap or gap between outputs and actual impacts with the desired outputs and impacts, then place this sequence of gaps on a priority scale and then choose the most important thing to solve the problem. Needs analysis is a formal process to determine the gap or gap between outputs and actual impacts. There are four categories of people who can be involved in need analysis, namely the target group, the audience, the needs analysis itself (need analysis) and resource groups (resource groups) [21]. Planning based on needs analysis carried out including identifying important objectives in the program, determining criteria or compiling criteria in accordance with the objectives of each indicator, ranking based on priorities in needs.

Implementation of planning in resident education depends on authority, responsibility and duties. Anesthesia Resident and Intensive Therapy will have different authorities, responsibilities and duties depending on the level of resident. There are 4 (four) levels, including Observer (may only observe patients, may not treat patients), Guard 1, Guard 2, and Chief. Each must pass a stage to advance to the next level. Analysis of the need for authority and assignment of residents to be very important to determine the appropriate treatment in the learning process.

Organizing is done based on the duties and authority of each component in the organization. Resident assistance in the form of simple counseling can be done through the stages of pre-conference, observation, and post-conference. Pre Conference is a stage based on the needs analysis for the purpose of mapping and grouping according to the stage. This section is used to detect resident readiness. This initial stage aims to avoid resident unpreparedness, prevent inequality in the implementation of learning. At this initial stage it can also be referred to as the preventive stage. Observation is the stage of implementing resident activities. Specialists as supervisors will observe and record positive things in journals, so that learning success is achieved. Post Conference is the final coaching activity in the form of personal dialogue to present a positive impression of success. In this section the importance of strengthening to grow motivation.

The mobilization or direction of the guidance program according to planning is the process of implementing the program according to its responsibilities with full awareness and high productivity. Implementation of the program or model that has been planned according to the expected goals. The role of leadership, mentoring, motivating residents to be able to work according to the main tasks and functions is very effective and efficient in achieving goals. Independence in learning and processing will support the positive development of themselves and others, while also supporting the positive development of emotional management which will ultimately affect the performance of the organization in accordance with the planned outcomes.

Education is an evidence based process. Teachers must use these findings to develop research that will guide them to find contextual factors in the classroom or school [22]. Continuing education not only strengthens the skills, knowledge and ability to solve problems but also decision making in academic interests and the development of learning [23]. Professional education of specialist doctors implements their evidence-based education programs and depends on the type of specialist chosen. Anesthesia Resident and Intensive Therapy must have intellectual abilities, skills and professional attitude in various diagnostic procedures and treatment of surgical and nonsurgical patients. Anesthesia Resident and Intensive Therapy must understand the needs of professionals in service at the ICU.

\section{RESEARCH METHOD}

The study was conducted with a qualitative approach to the type of Case Study. A qualitative approach is used because the data to be analyzed is in the form of words or verbally from the informants and/ or observed behavior. Data collected in the form of words or interpretation, not numbers. Narrative presentation in qualitative will produce data in the form of texts or images.

The researcher conducted a more structured systematic analysis compared to other qualitative studies. Researchers will use 2 (two) main methods, namely the method of interpretation of the data obtained and the method of creativity of researchers in developing assumptions into new theoretical phenomena or formulas. Researchers enter the process of carrying a few assumptions. Researchers not only describe or describe but also conceptualize the cases encountered.

Research data in the form of primary data and secondary data. Primary data is data obtained directly from research subjects. Primary data is generated from the subject's direct contact with the researcher in accordance with the objectives of each indicator that will reveal the need-based resident Anesthesiology and Intensive Therapy guidance model. Secondary data is indirect data obtained and extracted to provide support for research subjects. Research subjects are the main source of data to be asked for information related to the needs-based guidance model. 
Data collection can be done by observation, interview, documentation, and combined through FGD or personal data collection activities. Testing the validity of the data in qualitative research is intended to show no difference between reported/ findings with the actual state of the object under study. Data analysis techniques used are data collection, data reduction, data presentation, and drawing conclusions / verification. Data validity tests include the Credibility test, the Transferability test, the Dependability test, and the Confirmability test [24].

\section{RESULT AND DISCUSSION}

Intensive Care Unit (ICU) according to KMK 1778/ 2010 (D.1) is a part of an independent hospital, with special staff, special services aimed at the observation, treatment and therapy of patients suffering from injuries or lifethreatening diseases or potentially life threatening. Because of this special emergency situation, hospitals must prepare human resources and supporting infrastructures.

The ICU room at the Kariadi doctor's hospital in Semarang provides 24-hour services in emergency medical services. The hospital prepares medical human resources (HR) that support the service. KMK 1778/2010 states that medical resources working in ICU are medical personnel who have adequate knowledge of emergency emergencies. Medical personnel needed in anesthesia and emergency intensive care, including specialist doctors Anesthesia and Intensive Therapy. The workforce table of the KMK is written that the head of the ICU is an anesthesiologist or other specialist doctor who is trained in ICU (if there is no Anesthesiologist yet).

Given that interest, the need for anesthesiologists is very high. The Faculty of Medicine of Diponegoro University organizes specialist education programs for Anesthesia and Intensive Therapy. In the curriculum document, it is stated that the Anesthesia and Intensive Therapy study program has a vision and mission to be to become the center of superior Anesthesia and Intensive Therapy education. Competency of the Anesthesiology and Intensive Therapy Specialist-1 Medical Education program at the Faculty of Medicine of the University of Diponegoro refers to the Competency Standards of the Anesthesiology and Intensive Specialist Doctors issued by the College of Anesthesiology and Intensive Therapy.

The design of the activities carried out must pay attention to the programs that have been provided by the study program. This is in line with the opinion of the study program manager. In the below is a statement from the manager of the study program and resident companion regarding the importance of continually advising residents.

"Anesthesiologist resident is an anesthetist specialist candidate who must have anesthetic responsibilities and abilities. Considering specialist doctors have a high role in preoperative management, during surgery, and post surgery; intensive and critical care; competencies and actions that must be possessed by an anesthetist. In connection with that, the Anesthesia resident must be able to learn strongly to develop the ability to become a reliable anesthetist. Education preparation and preparation must be carried out correctly and on time. So that learning targets are exceeded".

"The level of complexity of learning is high and solid allows a resident to have a burden and management time that is not optimal. Interwoven communication and interaction is needed to design mentoring activities so that residents do not dissolve in the burden. In addition, self-regulation in self-regulation must be improved".

"Resident coaching is carried out with the aim of solving problems that arise during the education process. Guidance is carried out academic and non-academic in the hope that it can direct students to complete education on time with maximum results. Anesthesia Resident and Intensive Therapy must be able to plan well according to the rules set by the study program and the requirements of the College".

The results of the interviews showed that the coaching plan was conducted by the resident together with the needs-based counselor. Identification of needs is carried out in resident interaction and communication with all relevant parties. Resident must be able to manage themselves so as not to dissolve in physical and psychological exhaustion through increasing the ability of self-regulation.

Need-based mentoring is carried out by taking into account the basic principles 1) problem-based, 2) resources, 3) objectives, and 4) building systems. management guidance is always directed based on problems. The planning carried out is an activity identifying students' characteristics in learning [25]. Planning must be familiarized and carried out in accordance with the provisions, in order to achieve the objectives set. Planning maps are carried out with a matrix to describe each of the related components. In education planning can be determined how to effectively and efficiently to achieve goals. Planning from the resident will be useful to formulate the resident's needs in planning the mentoring program. some residents argued in favor of the planning activities. Below is a statement from the respondents who became the study sample. 
"Planning is carried out by senior residents who are at a higher stage. we just followed but we were questioned regarding the activities and tasks we had to do".

"Often we have planned, but some of us have sudden assignments, so we are always stuck. even so we are ready and always ready, because that's what we have to do".

"Planning must be followed by main duty mapping and implementation. don't just plan, but afterwards work away from planning".

Planning must be based on needs, based on the potential and characteristics of students. However, the resource factor and competency achievement targets must be considered. Planning is viewed from many sides and interests, including the study program, supervisor doctor, cologist, several other ICU lecturers, and several residents of Anesthesia and Intensive Therapy. Resources and guidance needs that must be considered include Administration and Facilities of ICU Infrastructure, Learning process for Resident Stase I, Learning Process for Resident Stase II, and Patient Service Process.

Identification of needs is outlined in the grouping of the meaning of these needs. Guidance identification is grouped from the needs of 1) residents, 2) specialist doctors / supervisors / supervisors, 3) teaching hospitals and networking hospitals as educational providers in addition to related study programs. This is in line with the statement from the network hospital management, as below.

"The organization of mentoring depends on the administration of the ICU, and the facilities of the ICU, because each is an independent part. The administration of the ICU and the layout of the ICU space will influence the planning of resident coaching. As mentioned by ICU Nurse".

"Guidance structuring will help residents to draw up plans in the event of difficulties in arranging scheduling. In addition, the layout of the ICU room will affect the comfort of mentoring ICU".

Identification of problems in mentoring needs concerns the type of problem, the actors involved, the dominant causes, and the impacts that arise from them. Problem analysis is carried out by observing the nature of the problem from macro to micro, then exploring the causes and alternative solutions. Every step obtained should lead from divergent to convergent. Priority for completion needs will be design priority.

The mobilization of the guidance process according to the plan made will make it easier to control the mentoring as an effort to achieve the target of resident competency. Guidance activities are developed from the perception of agreed perceptions to be carried out together in achieving goals. Enabling environment will support the success of the mentoring process. This is consistent with the statement of the resident companion, as disclosed below.

"Management of resident coaching in the ICU must pay attention to patient factors and matters related to patient administration services, so that residents understand how the characteristics of patient services are. Resident must also make a guidance schedule by adjusting the schedule of doctors in the ICU. All captured in the ICU administration".

This is consistent with the opinion of the Chair of the Study Program which states that:

"Guidance management is carried out by the resident by mapping the guidance needs and agreement with the supervisor".

Support for this opinion flowed from other ICU doctors and residents. According to the informants:

"Guidance management in the ICU room does not depend on ICU facilities and infrastructure, scheduled planning of the mentor's agreement with the resident and recorded by a higher level resident ".

"The results of observations carried out at the ICU runag show that there is management administration of the guidance, although not yet at the maximum, at the beginning of the learning activities. The design and schedule already exists but does not interfere with the administration and infrastructure of the ICU ".

Guidance management will be very meaningful in preparing for the implementation of processes and services in the ICU room. As described in the curriculum documents and work program documents the management of learning for residents of phase I and residents of phase II and services will be the basis for improving the quality of learning. The results of the interview with the supervisor doctor described the following matters:

"The resident will prepare the activity with the support of the availability of hospital facilities and infrastructure. Anesthesia Resident and Intensive Therapy will be candidates for the doctor's supervisor at the ICU, so they must explore their profound abilities to get maximum results ". 
"That the resident must be able to manage the learning activities as well as possible by not wasting the available opportunities. The resident must be able to add competence at each stage of learning provided. Guidance management should be carried out together with the team, by using the related facilities and infrastructure".

Anesthesiologist and Intensive Therapy physician self-development is very much needed in accordance with the Decree of the Minister of Health of the KMK 1778 / MENKES / SK / XII / 2010 which shows that the qualifications of health workers serving in the ICU must have adequate knowledge, appropriate skills, and a commitment to time. Further in document 1 also explained that doctors and medical personnel must always improve their ability to support self-development and patient services. The design of self-development is regulated independently and systematically. This becomes the basis for self-development of ICU doctors and / or medical personnel. This affects the management of coaching conducted by the resident as a specialist doctor candidate to maximize his potential.

Management of residency guidance for Anesthesia and Intensive Therapy must pay attention to supporting factors. Supporting factors are a priority scale to be developed, including: 1) self-management, including tolerance, responsibility, flexibility, and not easy to blame; 2) self-regulation, one's ability in the form of the ability to think and manipulate the environment so that changes occur. Self-regulation developed includes self-monitoring, selfdirecting, selfregulating of actions, 3) understanding of learning and learning interactions, learning and learning interactions will support the development of adaptation skills, independence (independent professionalism), and flexibility, and 4) assignments and The assignment will describe how far the resident understands and does the job well.

\section{CONCLUTION}

Need-based resident guidance planning is not maximized, which is indicated by lack of commitment and consistency. Guidance planning is only done in the same direction, so that it will reduce the significance of the guidance. Understanding the characteristics and potential of residents will strengthen the formulation of educational program planning. Organizing is done but it is not yet optimal. The organization of residents related to needs-based counseling only exists from and between stations, the direction or mobilization of residents in needbased mentoring is good and there are still shortcomings related to the consistency of coaching. Control of the model is carried out properly through supervision, monitoring, and evaluation.

\section{SUGGESTION}

Recommendations are given to 1 ) the resident must understand the overall learning design and the accompanying issues in order to be able to identify the achievements according to the target; 2) accompanying doctor, providing needs-based guidance. Therefore we need a high understanding of the characteristics and potential of students so that they are able to formulate guidance appropriately; and 3) civitas Anesthesiologist and Intensive Therapy Specialist Medical Education Program in particular can develop models into contextual models that can help realize the outcomes of study programs.

\section{REFERENCES}

1. Supriyatin, Dwi., Wulandari, Indah., Ekayanti, Sri. 2014. Pengaruh Penambahan Bubuk MCT (Medium Chain Triglyceride) dalam Makanan Enteral Komersial terhadap PaCO2 dan PaO2 Darah Pasien Kritis di RSUP Dr. Kariadi Semarang. Jurnal Medica Hospitalia, Vol 2 (2) : 115-119.

2. Suryadilaga, Yudhanta., Arifin, Johan., dan Ismail, Akhmad. 2015. Jumlah Kematian Pasien di Ruang Perawatan Intensif Berdasarkan Kriteria Prioritas Masuk RSUP dr. Kariadi Periode Juli-Desember 2014. Media Medika Muda, 4/ 4, http:// ejournal-s1.undip.ac.id/index.php/medico, acces on 07 Mei 2019

3. Ramadhan, Heru Noor. 2019. Pelaksanaan Pencegahan dan Pengendalian Ventilator Associated Pneumonia (VAP) di Ruang ICU. Journal of Hospital Accreditation, 1/ 1: 3-8.

4. Schwab, Kristin., Friedman, Jodi., Lazarus, Michael E., and Williams, Jason P. 2019. Preparing Residents for Emergent Vascular Access: The Comparative Effectiveness of Central Venous and Intraosseous Catheter Simulation-Based Training . International Journal of Critical Care and Emergency Medicine. Schwab et al. Int J Crit Care Emerg Med. Volume 5 | Issue 1 https:/ / DOI:10.23937/2474-3674/ 1510069 ISSN: 2474-3674.

5. Petri, Camille R.., Ranchoff, Brittany L., Cohen, Amy P., Sullivan, Amy M., Schwartzstein, Richard M., and Hayes, Margaret M. 2019. An Exploratory Study of Overnight Education in The Medical Intensive Care Unit. International Journal of Critical Care and Emergency Medicine. ISSN: 2474-3674, https:// DOI:10.23937/24743674/1510063, Vol 5 issue 1, p.1.

6. Konsil Kedokteran Indonesia. 2012. Standar Kompetensi Dokter Indonesia. Jakarta: KKI.

7. Nelson, G. A., King, M. L., \& Brodine. 2008. Nurse-Physician Collaborationon Medical-Surgical Units. Medsurg Nursing, 17/ 1, 35-40. 
8. Epstein RM., \&Hundert EM., 2002. Defining and Assessing Professional Competence. JAMA, 287(2): 226 - 235.

9. Kolegium. 2008. Standar Pendidikan Dokter Spesialis Anestesiologi dan Ilmu Terapi. Kolegium Ilmu Kesehatan Anestesi dan Ilmu Terapi Indonesia.

10.Rethans, JJ,. Norcini, JJ., Barón, Maldonado M., Blackmore D., Jolly BC., LaDuca T., Lew S., Page GG., Southgate LH. 2002. The Relationship Between Competence andPerformance: Implications for Assessing Practice Performance. Med Educ. 36(10), 901-9.

11.Brown, N \& Doshi, M. 2006. Assessing Professional And Clinical Competence: The Way Forward. Advances in Psychiatric Treatment, 12, 81 - 91.

12.Dunn, William N. 1994. Public Policy Analysis: Introduction. New Jersey: Prentice Hall International Inc.

13. Hays,W.L. 2002. Quantification in Psichology. New Delhi: Prentice Hall.

14.Joyce, Bruce. 2009. Models of Teaching: Advance Organizer. New Jersey: Pearson education Inc. 247-261

15.Epstein RM., \&Hundert EM., 2002. Defining and Assessing Professional Competence.JAMA, 287(2): 226 - 235.

16.Akib K, M., et al. 2008. Pedoman Pencegahan dan Pengendalian Infeksi di Rumah Sakit dan Fasilitas Pelayanan Kesehatan Lainnya. Jakarta: Departemen Kesehatan RI \&Perdalin.

17.Terry, G.R. 1978. Principles of Management. Homewood: Richard D. Irwin, Inc.

18.Robbins, Stephen P., dan Coulter, Mary. 2009. Manajemen Jilid 1. Jakarta: Erlangga.

19.Appley A, Lawrence dan Lee, Oey Liang. 2010. PengantarManajemen. Jakarta: Salemba Empat.

20.Chang A, Chou CL, Teherani A, Hauer KE. 2011. Clinical Skills-Related Learning Goals Of Senior Medical Students After Performance Feedback. Medical education, 45(9):878-885.

21.Kaufman, Roger A., \& English, Fenwick W. 1979. Needs Assessment: Concept and Application.New Jersey: Educational Technology Publications.

22.Hargreaves, R., J. 1997. In Defence of Reseach for Evidenced-Based Teaching: a Rejoinder to Martyn Hammersely. British Educational Reseach Journal. 23 : 405-420.

23.Pelonis, P., Cherif, A., and King, L. 2009. Preparing High School Students for College Success: a College and High School Leadership Collaborative. Journal of Higher Education Management. 24/ 1:68-77.

24.Sugiyono. 2015. Metode Penelitian Pendidikan (Pendekatan Kuantitatif Kualitatif dan R\&D. Bandung: Alfabeta.

25.Muhdi dan Murniati, N.A. N. 2015. Profil Manajemen Diri Guru SMP: Studi Kasus pada Guru SMP Mata Pelajaran Ujian Nasional Sub Rayon Semarang Utara. Jurnal Pendidikan dan Profesi Pendidik, 1/ 1:29-44. 